Respon Masyarakat Muslim Terhadap Keberadaan Umat Kristen di Cikawungading Cipatujah Tasikmalaya Tahun 1996-2019| Abdul Baits

\title{
RESPON MASYARAKAT MUSLIM TERHADAP KEBERADAAN UMAT KRISTEN DI CIKAWUNGADING CIPATUJAH TASIKMALAYA TAHUN 1996-2019
}

\author{
Abdul Baits \\ Pasca Sarjana UIN Sunan Gunung Djati Bandung \\ Email: abdulbaits96@gmail.com
}

\begin{abstract}
This study aims to explain how the Muslim community responded to the presence of Christians in Cipatujah, as it is known that Christians came to Cipatujah around 1936, namely Javanese people from Salatiga who were brought by the leadership of a Dutch missionary named Tuan A. Van Emmerik. The method used in this research is the historical method by carrying out the stages starting from data collection (heuristics), levers (criticism), interpretation (interpretation) and writing (historiography). Data collection techniques used in this research are text study, observation. and interviews. The results of this study show that there have been ups and downs of relations between Muslims and Christians in Cipatujah. This can be seen from several conflicts that have occurred from the riots in 1996 to the burning of churches and Christian settlements in 2001.
\end{abstract}

Keywords: Response, Muslims, Christians, Cipatujah. 
Respon Masyarakat Muslim Terhadap Keberadaan Umat Kristen di Cikawungading Cipatujah Tasikmalaya Tahun 1996-2019| Abdul Baits

\section{Pendahuluan}

Agama Islam cukup lama berkembang di daerah Jawa Barat bagian Selatan yaitu sejak abad $17 \mathrm{M}$. Mengenai masuk dan berkembangnya agama Islam di Jawa Barat menurut AA Khaerussalam dalam bukunya yang berjudul: Sejarah Perjuangan Syekh H. Abdul Muhyi Waliyullah Pamijahan, menyebutkan:

"Islam masuk ke Jawa Barat pada tahun $1511 \mathrm{M}$, dibawa oleh para pedagang dari Malaka. Akan tetapi penyebaran yang meluasnya adalah oleh Fatahilah atau Sunan Gunung Djati. Ketika beliau datang di Jawa Barat yaitu di Sunda Kelapa, disana masih merupakan kekuasaan orang Hindu di bawah Kerajaan Majapahit, sedangkan sebagian besar Indonesia pada waktu itu dikuasai oleh kerajaan Demak. Berkat perjuangan Fatahilah dengan izin raja Demak yaitu Sultan Trenggana, maka tersiarlah agama Islam ini secara meluas di Jawa Barat sekitar tahun 1527 M."1

Sedangkan di Jawa Barat bagian Selatan tepatnya di wilayah Kabupaten Tasikmalaya, pada masa itu penyebaran agama Islam sedang dirintis oleh seorang wali yang bernama Syekh H. Abdul Muhyi. Beliau menjadikan daerah Pamijahan sebagai pusat penyebaran agama Islam yang bertempat di Goa Saparwadi.

Proses Islamisasi tersebut terjadi sekitar tahun 1678-1730 M. Dimana pada tahun 1677 M Syekh Abdul Muhyi mendapatkan perintah dari gurunya yang bernama Syeh Abdul Ra'uf dari Gersik, untuk menyebarkan Islam di wilayah Jawa Barat dan mencari sebuah Goa dengan ciri-ciri: apabila di sekitar Goa tersebut ditanam padi maka hasilnya sebenih, artinya ketika dipanen jangan melimpah tetapi harus tetap sebenih yang ditanamkan tadi. Kemudian harus menetap di sekitar Goa tersebut sambil menyebarkan ajaran Agama Islam. $^{2}$

Setelah beliau berjuang merintis agama Islam, baik melalui pengkaderan para santri-santrinya maupun syiar Islam ke berbagai tempat di daerah Tasik Selatan, maka agama Islam dapat diterima di masyarakat dengan baik. Syekh abdul Muhyi wafat pada tanggal 8 Jumadi Awal tahun 1151 H/1730 M. ${ }^{3}$

1 A.A Khaerussalam, Sejarah Perjuangan Syekh H. Abdul Muhyi Waliyullah Pamijahan, (Tasikmalaya: Grafiana Offset. Cet IX 1997). . 9-10

${ }^{2}$ AA. Khaerussalam, Sejarah Perjuangan....... 9-11

${ }^{3}$ AA. Khaerussalam, Sejarah Perjuangan ....... 26-29 
Setelah beliau wafat dan dimakamkan di daerah Pamijahan sekarang, syi'ar Islam kemudian diteruskan oleh para santrinya, salah satunya adalah Syekh Zaenudin Sinuhun yang kemudian menyebarkan agama Islam di daerah Cipatujah termasuk di wilayah Cikawungading.

Syekh Zaenudin Sinuhun merupakan salah seorang santri Syekh Abdul Muhyi yang menetap di daerah Bantarkalong Kecamatan Cipatujah Kabupaten Tasikmalaya sekarang. Beliau menyabarkan agama Islam di daerah ini dengan cara seperti yang dilakukan gurunya (Syekh Abdul Muhyi) yaitu dengan Tarekat dan pendidikan yang terjadi sekitar tahun $1770 \mathrm{M}$. Sebagai buktinya adalah adanya Goa sarongge di Pesantren Muara sampai sekarang yang berada di Bantarkalong Kecamatan Cipatujah. ${ }^{4}$

Penyebaran Islam di Cikawungading ini diperkirakan terjadi pada tahun 1799 M yang dilakukan oleh Syekh Zaenudin Sinuhun dengan dibantu para santrinya yang berasal dari pesantren Muara tersebut, sehingga Islam akhirnya dapat berkembang dan diterima masyarakat Cikawungadaing sampai sekarang, walaupun penyebaran Islamnya masih di wilayah pesisir Pantai Cipatujah. Penyebaran Islam pun belum secara Kaffah (menyeluruh) artinya masih terdapat unsur-unsur tradisi lokal yang di legitimasi oleh pengaruh agama lokal seperti Islam Kejawen dan yang lainya. Dengan kata lain masih terjadi singkretisme ketiga kebudayaan Islam, agama Lokal dan Hindu tersebut. ${ }^{5}$

Meskipun demikian agama Islam memiliki pengaruh yang sangat kuat. Hal ini terbukti bahwa seluruh masyarakat Desa Cikawungading yang mayoritas beragama Islam mereka meyakininya sebagai agama yang paling benar. Agama Islam berkembang di daerah ini secara turun temurun begitupun dengan ajaran-ajaranya.

Agama Islam di daerah ini dianggap sebagai sistem keyakinan dan tata kaidah Illahiyah yang mengatur segala perikehidupan dan penghidupannya dalam berbagai hubungan, baik hubungan manusia dengan sesama manusia maupun hubungan manusia dengan alam lainnya. ${ }^{6}$

Pada tahun 1936 agama Kristen Protestan memasuki daerah ini sebagai agama baru yang sama seperti agama Islam memiliki ajaran dan tata nilai pada

${ }^{4}$ Ujang Setiawan, Konflik antara Islam dengan Kristen Protestan di Kelaksanan Desa Cikawungading Kecamapat Cipatujah kabupaten Tasikmalaya Tahun 2001. (Bandung: Skripsi UIN Sunan Gunung Djati Bandung, 2005). . 50

${ }^{5}$ Ujang Setiawan, Konflik antara Islam dengan Kristen Protestan ...... . 52 1992)

${ }^{6}$ Endang Saefudin Anshari, Kuliah Al-Islam (Jakarta: P.T. Raja Grafindo Persada. 
kehidupan manusia. Agama Kristen Protestan ini diperkenalkan oleh bangsa Belanda yang membuka areal perkebunan di Kalaksanan Desa Cikawungading. ${ }^{7}$

Sebagaimana dikatakan oleh Supardi sebagai sesepuh Gereja yang menyebutkan bahwa: sekitar tahun 1936 M pada waktu itu umat Kristen mendapatkan surat keputusan pemerintah No.15 Tanggal 18 Agustus 1936, Lembaran Negara No.176 Tanggal 17 April 1936 yang berisi tentang pendirian Gereja dan pengembangan agama Kristen Protestan. Sedangkan jemaatnya berasal dari Salatiga Jawa Tengah di bawah kepemimpinan Gereja Kristen Jawa (GKJ).

Para pemeluk agama Kristen berupaya mempertahankan dan mengajak masyarakat untuk memeluk agamanya dengan cara mengamalkan "Hukum Kasih" yaitu menyayangi dan mengasihi sesama manusia. Dengan demikian, agama Krsiten Protestan dapat berkembang di daerah Kalaksanan desa Cikawungading. ${ }^{8}$

Kehadiran agama Kristen Protestan di Kalaksanan menjadikan para pemeluk agama Islam khawatir akan eksistensi agamanya, akan tetapi mereka tidak bisa apa-apa. Artinya para pemeluk agama Islam tidak bisa mengadakan perlawanan atau menolak keras terhadap keberadaaan agama Kristen Protestan tersebut. Hal ini disebabkan oleh situasi dan kondisi politik, ekonomi, dan taraf pendidikan mereka yang tidak mendukung pada saat itu.

\section{Metode}

Metode yang digunakah dalam penelitian ini adalah metode sejarah dengan melakukan tahapan-tahapan mulai dari pengumpulan data (heuristik), kritik sumber (verifikasi), penafsiran (interpretasi) dan penulisan (historiografi). ${ }^{9}$ Selain menggunakan konsep (library research), teknik pengumpulan data yang dilakukan dalam penelitian ini adalah studi naskah,

${ }^{7}$ Supardi (63 tahun). Pengurus Majlis Jemaat Gereja Kristen Pasundan Kalaksanan periode 2014 - 2018, sekaligus generasi ke empat sebagai sesepuh gereja. Wawancara, pertama, hari Minggu 5 Januari 2020 di Kalaksanan.

${ }^{8}$ Pdt. Arni Selvi Mince. B (30 tahun). Kepala Pendeta Gereja Kristen Pasundan Kampung Kalaksanan. Wawancara, hari Minggu tanggal 19 Maret 2018 di Kalaksanan.

${ }^{9}$ Lihat Kuntowijoyo, PengantarIlmuSejarah, Yogyakarta: Bentang, 1997. Bandingkan dengan Helius Sjamsudin, Metodologi Sejarah, Jakarta: Departemen P\&K, Direktorat Pendidikan Tinggi. 1996, Sartono Kartodirdjo, Pendekatan Ilmu-ilmu Sosial dalam Metodologi Sejarah, Jakarta: Gramedia, 1992, dan Louis Gottschalk, Mengerti Sejarah, Jakarta: Universitas Indonesia, 1975. 
Respon Masyarakat Muslim Terhadap Keberadaan Umat Kristen di Cikawungading Cipatujah Tasikmalaya Tahun 1996-2019| Abdul Baits

observasi dan interview. Observasi dilakukan untuk mengetahui keberadaan serta kondisi mayarakat Kristen yang ada di Kp. Kalaksanan Cipatujah. Interview dilakukan untuk mendapatkan informasi lisan secara langsung dari pelaku dan saksi baik itu masyarakat Isam, Kristen serta Tokoh Masyarakat dan Tokoh Pemerintahan setempat.

\section{Pembahasan}

\section{A. Sejarah Masuknya Agama Kristen di Cipatujah}

Di Jawa Barat, ajaran agama Kristen (Katolik \& Protestan) bisa dibilang berkembang, meskipun tidak segencar di daerah yang lainnya karena mengalami kesulitas-kesulitan ketika mereka harus mengkristenkan orangorang Sunda. Oleh karna itu bia kita lihat komunitas-komunitas umat Kristen di daerah Jawa Barat basis penyebaran agama Kristen yang cukup kuat adalah di Sukabumi, Kuningan dan Cianjur. Hal ini tampak dengan banyaknya sarana aktivitas keagamaan dan pendidikan Kristen.

Kristen datang ke wilayah ini sekitar tahun 1936 yaitu orang-orang Jawa dari Salatiga yang dibawa oleh pimpinan Misionaris Belanda bernama tuan A.Van Emmerik. ${ }^{10}$ Orang-orang Kristen yang dibawa ke Cipatujahpada saat itu di bawah kepengurusan GKJ (Gereja Kristen Jawa). Tujuan utama dibawanya mereka ke wilayah Cikawungading Cipatujah ini pada awalnya untuk membuka lahan pertanian. Namun dikarenakan orang-orang Jawa yang dibawa beragama Kristen akhirnya mendirikanlah sebuah tempat peribadatan (Gereja) walaupun sebenarnya misi orang-orang Belanda pada saat itu untuk melaksanakan pekabaran Inzil (zending). Selain itu, orang-orang Jawa ini di pekerjakan di perkebunan milik pemeritah Kolonial Belanda sebagai pekerja perkebunan karet, kelapa, kopi dan yang lainya. Tidak hanya di pekerjakan, orang-orang Jawa ini juga mendapat tanah garapan sekaligus mendapat pembinaan iman dari para Zendeling dan para guru Injil dari GKJ. (Gereja Kristen Jawa) ${ }^{11}$

Menyebarnya agama Kristen di kampung Kalaksanan Desa Cikawungading diantaranya melalui perkawinan dengan sesama orang Kristen

${ }^{10}$ Keputusan Pemerintah NO. 15 Tanggal 18 Agustus Tahun 1936 dan Lembaran Negara No. 176 Tanggal 17 April 1936 Tentang Pendirian Gereja dan Pengembangan Agama Kristen Protestan.

${ }^{11}$ Supardi (63 tahun). Pengurus Majlis Jemaat Gereja Kristen Pasundan Kalaksanan periode 2014 - 2018, sekaligus generasi ke empat sebagai sesepuh gereja. Wawancara, pertama, hari Minggu Minggu 5 Jaunari 2019 di Kalaksanan. 
dari Jawa itu sendiri dan dengan penduduk sekitar yang bisa dikatakan beragama Islam. Selain dari itu, perkembangan agama Kristen di Kalaksanan dipengaruhi oleh faktor ekonomi, adanya hubungan dagang, kerjasama antara orang Kristen dan Muslim pada saat itu. ${ }^{12}$

Ketika terjadi pergantian penguasa di Indonesia dari Belanda kepada Jepang, maka orang-orang Belanda yang membina orang-orang Kristen di Kalaksanan di kembalikan ke Negaranya. Orang-orang Kristen di Kalaksanan diserahkan kepada pelayanan GKJ (Gereja Kristen Jawa) dibawah pelayanan Probowinoto. Namun karena kesibukanya, pelayanan kemudian diserahkan kepada adiknya yaitu guru Injil Siswopaminto. Akan tetapi, karena sulitnya medan yang harus ditempuh untuk melakukan pelayanan di kalaksanan, maka pembinaan iman sehari-hari di layani oleh Pdt. Kasmino salah seorang warga kristen Kalaksanan. Pelayanan tersebut berlangsung sampai tahun 1949. ${ }^{13}$

Pada masa pendudukan Jepang, perkembangan agama Kristen di Kalaksanan Desa Cikawungading mengalami hambatan-hambatan dalam mengembangkan misi agamanya, karena pada saat itu, Jepang masuk ke daerah Kalaksanan desa Cikawungdaing. Selain dari itu, pada tahun 19761979, agam Kristen mendapatkan reaksi atau perlawanan dari umat Islam terhadap cara penyebaran misi dakwahnya. Sejak saat itu misi dakwah mereka terpusat hanya kepada keluarga yang beragama Kristen, membina jemaat yang sudah ada dalam mengamalkan ajaran agama Kristen dan tidak untuk mempengaruhi agama lain di luar itu. Kemudian para tokoh-tokoh agama Kristen mengevaluasi kembali bagaimana mengembangkan misi keagamaanya tersebut. Sejak saat itu, umat Islam akhirnya memahami dan menghormati bahkan menerima kembali keberadaanya. ${ }^{14}$

Pada tahun 1950 di Jawabarat terjadi pergolakan DI/TII (darul islam/tentara islam indonesia) dibawah pimpinan S.M. Kartosuwiryo. Pemberontakan ini menyebabkan banyak orang Kristen di Jawabarat mengalami gangguan, juga mengganggu kelangsungan persekutuan orang Kristen di Kalaksanan bahkan kebaktian Minggupun tidak berjalan. Pada

${ }^{12}$ Dadang Suhermawan (46 tahun) Kepala Desa Cikawungading. Wawancara, hari Sabtu 8 Febuari 2019 di Kantor Kepala Desa Cikawungading.

${ }^{13}$ Pdt. Arni Selvi Mince. B (30 Tahun). Ketua Pendeta di Gereja Kristen Pasundan Kampung Kalaksanan. Wawancara, pertama, Hari Minggu Minggu 19 Januari 2019 di Kalaksanan. Kalaksanan.

${ }^{14}$ Supardi (63 tahun)....... Wawancara, pertama, hari Minggu 5 Jaunari 2019 di 
Respon Masyarakat Muslim Terhadap Keberadaan Umat Kristen di Cikawungading Cipatujah Tasikmalaya Tahun 1996-2019| Abdul Baits

tahun 1962 DI/TII di bawah Kartosuwiryo dapat di tumpas maka kondisi keamanan di Kalaksanan berangsur-angsur membaik dan kehidupan persekutuan jemaatpun berangsur-angsur pulih. Seiring dengan pulihnya keadaan keamanan. Setelah peristiwa itu, di Kalaksanan terdapat 7 keluarga yang masih ada yaitu: keluarga Kasmono, keluarga Lipur Suparto, keluarga Saribun, keluarga Rusmin, keluarga Markus, keluarga Andras dan keluarga Ibu Martah. Untuk pembinaan iman selanjutnya mereka menghubungi GKP (Gereja Kristen Pasundan) di kota Tasikmalaya. Akhirnya pada tahun 1959 warga Kristen Kalaksanan tercatat sebagai anggota GKP (Gereja Kristen Pasundan). ${ }^{15}$

Dalam perkembangan selanjutnya, GKP (Gereja Kristen pasundan) Jemaat Kalaksana mulai bertumbuh kembali. Pada tahun 1990 anggota jemaatnya telah terdiri dari 50 Kepala Keluarga pada tahun 1992 di tahbiskanlah seorang Pendeta di GKP (Gereja Kristen Pasundan) Jemaat Kalaksanan yaitu Pdt. Yanto Suprianto Jian. Beliau melayani di GKP (Gereja Kristen Pasundan) Jemaat Kalaksanan sampai tahun 1997. Menjelang akhir masa pelayanannya, pada tanggal 26 Desember 1996 terjadi pembakaran terhadap gedung Gereja GKP (Gereja Kristen Pasundan) Jemaat Kalaksanan. Pembakaran ini terjadi hampir di seluruh gereja-gereja se-kabupaten Tasikmalaya. Namun aksi ini tidak menghentikan kelangsunan kehidupan kehidupan pelayanan GKP (Gereja Kristen Pasundan) Jemaat Kalaksanan. ${ }^{16}$

Untuk mengisi kekosongan pelayanan di GKP (Gereja Kristen Pasundan) Jemaat Kalaksanan, di tunjuklah Pdt. Megina Hanafiah dari GKP (Gereja Kristen Pasundan) yang ada di kota Tasikmalaya dan Pdt. Aam R. Sairoen, dari GKP (Gereja Kristen Pasundan Garut sebagai pendeta konsulen. Pada tahun 2001 Pdt. Megiana Hanafiah pindah dari GKP (Gereja Kristen Pasundan) kota Tasikmalaya untuk kemudian pindah ke GKP (Gereja Kristen Pasundan) Bogor. Sejak saat itu konsulensi dipegang oleh Pdt Aam R. Sarioen. Pada tanggal 17 September 2001 terjadi kembali pembakaran gereja dan pengrusakan untuk kedua kalinya dalam kehidupan GKP (Gereja Kristen Pasundan) Jemaat Kalaksanan. Dalam peristiwa ini tidak hanya gedung gereja yang dibakar tetapi juga 21 rumah warga jemaat Kristen dan rumah warga Muslim lainya. Namun kemudian banyak orang dan gereja yang bersimpati

\footnotetext{
di Kalaksanan.

${ }^{16}$ Pdt. Arni Selvi Mince. ...... Wawancara, pertama, Hari Minggu 19 Januari 2019 di Kalaksanan.
}

${ }^{15}$ Pdt. Arni Selvi Mince. B ..... Wawancara, pertama, Hari Minggu 19 Januari 2019 
Respon Masyarakat Muslim Terhadap Keberadaan Umat Kristen di Cikawungading Cipatujah Tasikmalaya Tahun 1996-2019| Abdul Baits

untuk membantu Jemaat Kalaksanan. Setelah itu, kehidupan Jemaat Kalaksanan berangsur pulih, walaupun menyisakan trauma yang mendalam bagi warga jemaat. ${ }^{17}$

Menurut Pdt. Arni Selvi Bitjara, setelah melalui proses perjalanan yang sangat panjang, akhirnya pada tahun 2005 di tetapkanlah Pdt. Hendrato, untuk menjadi Pendeta Konsulen GKP (Gereja Kristen Pasundan) Kalaksanan dan pada tahun 2007 ditahbiskanlah seorang Vikaris R. Bonavarte kedalam jabatan Pendeta Jemaat Kalaksanan hingga tahun 2012. Untuk meneruskan pelayanan di GKP (Gereja Kristen Pasundan) Kalaksana, maka pada tanggal 10 Juni 2012 bersamaan dengan pengakhiran masa pelayanan Pdt. R. Bonavarte diresmikanlah pula seorang Vikaris yaitu Arni Selvi Mince Bitjara yang kini menetap di kalaksanan dan Pdt. Hendrato, selaku pendeta konsulen dari kota Tasikmalaya. Maret 2014 Vikaris Arni Selvi Bitjara ditahbiskan menjadi pendeta GKP (Gereja Kristen Pasundan) dengan basisi pelayanan di Kalaksanan hingga saat ini.

Agama Kristen Protestan di kampung Kalaksanan desa Cikawungading kabupaten Tasikmalaya dapat berkembang dengan baik dan diterima oleh warga masyarakat terutama yang beragama Islam. Keberadaan masyarakat Kristen Protestan tersebut tetap ada dan eksisi sampai sekarang.

\section{B. Perjumpaan Agama Islam dan Kristen Protestan di Cikawungading Cipatujah}

Pekabaran Injil di Jawa Tengah tepatnya di Salatiga memberikan pengaruh yang sangat besar bagi terbentuknya komunitas Kristen yang ada di Kampung Kalaksanan Desa Cikawungading Kabupaten Tasikmalaya sebelum nantinya menjadi bagian dari GKP (Gereja Kristen Pasundan).

Di Kampung Kalaksanan Desa Cikawungading Kabupaten Tasikmalaya, agama Islam sudah terlebih dahulu disebarkan oleh para wali yaitu Syekh Abdul Muhyi dan muridnya meskipun pada saat itu agama Islam hanya tersebar di wilayah pesisir pantai Cipatujah saja dan masih terdapat unsur ajaran Islam dan ajaran nenek moyang mereka (Islam Kejawen). ${ }^{18}$

Perjumpaan antara agama Islam dan Kristen di kampung Kalaksanan tidak terjadi secara langsung ketika agama Kristen datang ke wilayah ini Kalaksanan.

${ }^{17}$ Pdt. Arni Selvi Mince. ........Wawancara, pertama, Hari Minggu 19 Januari 2019 di

18 A.A Khaerussalam, Sejarah Perjuangan Syekh H. Abdul Muhyi Waliyullah Pamijahan, (1997). .6 
karena pada saat itu agama Kristen yang dibawa dari Salatiga pertama kali dibawa oleh para misionaris Belanda ke wilayah pedalaman untuk membuka lahan pertanian sehingga perjumpaan di antara Islam dan Kristen terjadi seiring berkembangnya zaman dan bertambah luasnya pemukiman. ${ }^{19}$

Pada awal keberadaanya orang-orang Kristen tidak banyak melakukan interaksi secara langsung dengan orang-orang Islam, baik itu dalam bidang perekonomian, pertanian, agama, politik, pernikahan, seni budaya maupun sosial lainya. Mereka (orang Kristen) hanya berfokus mengerjakan pertanian di wilayah pedalaman (kampung Kalaksanan sekarang). Apalagi kondisi pada saat itu Indonesia masih dalam keadaan terjajah oleh bangsa Belanda. Baik Islam maupun Kristen seakan mempunyai kehidupan masing-masing, orangorang Islam hidup di wilayah pesisir pantai Cipatujah dan orang Kristen hidup di wilayah pedalaman.

Pada perkembangan selanjutnya perjumpaan antara Islam dan Kristen di kampung Kalaksanan Desa Cikawungading sudah mulai terlihat, interaksi antara orang-orang Islam dan Kristen sudah mulai terjadi baik dalam bidang sosial kemasyarakatan, politik, perdagangan (ekonomi), perkawinan dan agama (pembanguan tempat peribadatan). Masyarakat Islam yang ada di pesisir mulai mencari kebutuhan hidupnya ke pedalaman. Hal ini bisa dilihat dengan banyaknya mereka yang mulai membuka hutan sebagi lahan pertanian dan tempat tinggal penduduk. Begitupun masyarakat Kristen mulai mencari kebutuhan hidupnya ke wilayah pesisir, hal inipun bisa dilihat dengan adanya masyarakat Kristen yang berprofesi sebagai nelayan dan pedagang di wilayah pesisir pantai Cipatujah.

Adapun Hubungan antara Islam dan Kristen di Cikawungading Cipatujah dapat dilihat dari beberapa aspek yaitu:

\section{Kehidupan Sosial Bermasyarakat}

Masyarakat Desa Cikawungading merupakan tipe masyarakat multikultural dimana mereka hidup dalam satu lingkungan dengan berbagai macam karakteristik dan kepercayaan yang berbeda (Islam dan Kristen). Selain itu masyarakat Desa Cikawungading tergolong masyarakat yang berbetuk paguyuban, dimana bentuk kehidupan bersama yang anggota-anggotanya diikat oleh hubungan batin yang murni dan

${ }^{19}$ Supardi (62 tahun). Pengurus Majlis Jemaat Gereja Kristen Pasundan Kalaksanan periode 2014 - 2018, sekaligus generasi ke empat sebagai sesepuh gereja. Wawancara, pertama, hari Minggu 5 Jaunari 2019 di Kalaksanan. 
Respon Masyarakat Muslim Terhadap Keberadaan Umat Kristen di Cikawungading Cipatujah Tasikmalaya Tahun 1996-2019| Abdul Baits

bersifat alamiah serta bersifat kekal. Dalam masyarakat Kampung Kalaksanan Desa Cikawungading bentuk paguyuban biasanya dilihat dari sistem kekerabatan, keluarga dan pola pemukiman yang saling berdampingan.

Pola sikap toleransi dalam hubungan sosial kemasyarakatan yang berkembang di Desa Cikawungading secara nyata telah menunjukan pada kehidupan sosial yang integrasi atau dalam bentuk kerukunan. Hal ini dibuktikan bahwa selama masyarakat setempat tinggal berdampingan dan dalam satu lingkungan yang sama hampir tidak ada konflik yang secara langsung mengatasnamakan penghinaan agama.

Seperti yang dikatakan oleh Supardi (sesepuh Gereja Kristen Pasundan) di Kampung Kalaksanan. Dalam hubungan sosial kemasyarakatan terutama antar masyarakat Islam dan Kristen tidak pernah ada masalah. Adapun masalah yang pernah terjadi yaitu pada tahun 1996 pernah terjadi pembakaran Gereja dan ruang Pastori itu datangnya dari orang-orang luar, jadi bukan karena orang Kristen dengan orang muslim di Kalaksanan. Hal ini juga terulang pada tahun 2001 juga pernah ada pembakaran Gereja dan rumah penduduk 25 rumah Kristen sebagian rumah warga Muslim dan dua Gereja.

Menurut Supardi "sampai saat ini puji Tuhan hubungan antara umat Islam dan Kristen semakin membaik." Sifat gotong royong ditunjukan bersama baik ketika umat Islam membangun Mesjid, umat Kristen ikut serta membantu dan sebaliknya. ${ }^{20}$ Kehidupan yang kian terjaga tercipta karena adanya keterkaitan antara norma yang menjadi acuan masyarakat dengan nilai-nilai agama maupun nilai adat atau kebudayaan yang kemudian menjelma dalam sikap dan cara kehidupan sehari-hari.

Dalam hubungan sosial kemasyarakatan mereka menunjukan sikap toleransi yang sama baik Islam maupun Kristen. Seperti halnya membangun Jalan, Mesjid, Gereja dan sarana prasarana keagamaan. Semua masyarakat baik laki-laki, perempuan, remaja, mereka semuanya antusias bergotongroyong (kerjabakti). Tidak hanya masyarakat Kristen, dari Gereja pun turut ikut bergotongroyong (kerjabakti). Contohnya disini

${ }^{20}$ Supardi (63 tahun)....... Wawancara, prtama, hari Minggu 5 Jaunari 2019 di Kalaksanan. 
yang baru kemaren membangun tempat belajar sekolah umat Kristen "Sekolah Minggu" masyarakat Muslim semuanya ikut membantu. ${ }^{21}$

Sikap toleransi antara Islam dan Kristen di Kampung Kalaksanan Desa Cikawungading secara jelas bisa dilihat dalam kehidupan sosial kemasyarakatan (gotong royong). Baik itu yang bersifat pribadi seperti membantu membangun rumah, ataupun yang bersifat umum seperti membangun rumah ibadah, jalan umum dan sekolah. Meskipun mengalami pasang surut, namun setidaknya mereka konsisten dengan sikap tersebut sehingga selalu tercipa sikap toleransi yang baik diantara keduanya. $^{22}$

\section{Politik}

Partisipasi masyarakat Islam dan Kristen dalam bidang politik di Kampung Kalaksanan menunjukan adanya kesamaan hak hidup diantara keduanya, mereka menunjukan sikap toleransi yang tinggi, mewujudkan keharmonisasian dan bersama-sama membangun daerah Kampung Kalaksanan demi terciptanya kerukunan hidupbersama.

Menurut Dadang Suhermawan Kepala Desa Cikawungading. Selaku Kepala Desa tidak membatasi masyakatnya untuk berpartisipasi dalam politik baik Islam maupun Kristen mereka semua mempunyai hak yang sama sebagai sesama warga masyarakat Kampung Kalaksanan. Namaun, kembali lagi kepada kondisi masyarakat itu sendiri, mayoritas masyarakat di Kampung Kalaksanan kurang berpartisipasi dalam politik hal ini dikarenakan tingkat pendidikan yang rendah. Keterlibatan mereka dalam politik terutama masyarakat Kristen di tingkat desa, hanya samapi menduduki RW (rukun warga) RT (rukun tetangga) dan Hansip. Tercatat warga Kristen yang aktif sebagai perangkat desa RW 1, RT 2 , Kader 3 dan Hansip $1 .^{23}$

\section{Ekonomi}

Masyarakat Islam dan Kristen di Kampung Kalaksanan Desa Cikawungading mayoritas bermata pencaharian sebagai petani. Pada umumnya masyarakat memanfaatkan hutan untuk dijadikan lahan pertanian, ditanami berbagai macam tanaman seperti kayu, kelapa, karet

${ }^{21}$ Sukati (61 tahun). Masyarakat Muslim. Wawancara, hari Sabtu 18 Januari 2019 di Kampung Kalaksanan.

${ }^{22}$ Sukati (61 tahun)...... Wawancara, pada hari Sabtu 18 Januari 2019 di Kalaksanan.

${ }^{23}$ Dadang Suhermawan (46 tahun).......Wawancara, Kedua, hari Minggu Sabtu 8 Febuari 2019 di Kantor Desa Cikawungading. 
dan kopi. Selain itu masyarakat juga bermata pencaharian sebagai nelayan karena di wilayah ini terdapat pelabuhan untuk mencari ikan dan sebagian masyarakatnya ada juga yang menjadi PNS. Disamping penduduk yang mayoritas bermata pencaharian sebagai petani adapula sebagian kecil masyarakat yang bermata pencaharian sebagai peternak seperti beternak ayam, domba, kambing dan sapi. ${ }^{24}$

Sikap seperti itu di tunjukan oleh masyarakat Islam dan Kristen di Kampung Kalaksanan, sebagai masyarakat desa mereka menunjukan ciri sebagai masyarakat yang homogen, sikap toleransi dalam berbagai aktifitas perekonomian berjalan dengan cara kerjasama dan saling membantu satu samalain.

\section{Pendidikan}

Bagi masyarakat kampung Kalaksanan Desa Cikawungading pada dasarnya belum sepenuhnya menyadari pentingnya sebuah pendidikan. Hal ini dapat terlihat dari tingkatan pendidikan masyarakat yang sangat rendah, di samping itu prasarana pendidikannya pun kurang memadai terutama pendidikan yang bersifat formal.

Tingkat pendidikan di Desa Cikawungading masih tergolong rendah, hal ini terlihat dari persentase tamat Sekolah Dasar. Pada umumnya masyarakat hanya menyekolahkan anaknya sampai tingkat Sekolah Dasar sebab mempunyai beberapa kendala untuk menyekolahkan anaknya ke jenjang yang lebih tinggi. Kendala yang paling utama lemahnya tingkat pendidikan di Desa Cikawungading adalah faktor ekonomi, sebab mayoritas penduduk bermata pencaharian sebagai petani dan banyak anggapan masyarakat bahwa sekolah itu mahal, masyarakat lebih mendorong anak itu untuk bekerja baik itu membantu pekerjaan orang tuanya maupun kerja diluar kota. ${ }^{25}$

Meskipun demikian sikap toleransi antar umat beragama di dalam kehidupan masyarakat sudah ditanamkan secara baik terutama dalam bidang pendidikan baik formal maupun non formal. Di kampung Kalaksanan sendiri terdapat dua pendidikan formal bagi anak usia dini. Bagi anak-anak yang beragama Islam mereka belajar di PAUD dan DTA sedangkan bagi anak-anak yang beragama Kristen mereka belajar khusus

\footnotetext{
${ }^{24}$ Data Monografi dan Demografi Desa Cikawungading Tahun 2018

${ }^{25}$ Dadang Suhermawan (46 tahun).......Wawancara, hari Minggu Sabtu 8 Febuari
} 2019 di Kantor Desa Cikawungading. 
Respon Masyarakat Muslim Terhadap Keberadaan Umat Kristen di Cikawungading Cipatujah Tasikmalaya Tahun 1996-2019| Abdul Baits

di Sekolah Minggu. Setelah mereka (anak-anak Islam dan Kristen) menginjak ke sekolah dasar (SD) mereka sekolah di tempat yang sama yaitu di SDN Pantilaksanan.

Sejak dulu sampai sekarang anak-anak sekolah yang beragama Islam dan Kristen biasa-biasa saja. Rutinitas belajar anak-anak sama, tidak ada perbedaan. Tidak hanya dalam matapelajaran yang bersifatnya umum, bahkan matapelajaran agama pun seperti PAI (pendidikan agama islam) mereka anak-anak yang Kristen ikut belajar sama-sama dengan anak-anak yang beragama Islam. Yang membedakanya di sini adalah ketika waktu ujian tengah semester dan akhir semester bagi anak-anak kristen di berikan soal ujian keagamaan khusus dari pihak gereja. Itu di lakukan di tingkat SD, SMP dan SMA bahkan perguruan tinggi. Di SDN Pantilaksana sendiri, dari jumlah murid 176 terdapat siswa yang beragama Kristen 16 orang dan 1 guru sekolah senior. ${ }^{26}$

Untuk kegiatan hari-hari besar keagamaan yang sifatnya umum seperti kalau di Islam sendiri seperti peringatan PHBI (peringatan hari-hari besar islam). Kalau di agama Kristen sendiri seperti hari raya Paskah, baik Islam maupun Kristen semuanya saling membantu dan antusias terutama pada kegiatan berupa kesenian, hiburan dan yang lainya. Selin itu ada juga yang sifatnya khusus seperti, di Bulan Rahamdhan bagi anak-anak yang beragama Islam ada yang namanya sekolah Romadhon (pesantren kilat), bagi anak-anak yang beragama Kristen pun sama mereka mempunyai kegiatan belajar di Gereja. ${ }^{27}$

Menurut Supatman Kepala Sekolah di SDN pantilaksanan, melihat hubungan antara umat Islam dan Kristen cukup baik khususnya dalam bidang pendidikan, sebagai pengajar di sekolah justru sering kerja sama dengan pihak Gereja terkait dengan masalah pendidikan dan pembelajaran anak-anak didik. Malah kalu di bandungkan dengan yang beragaama (Islam) perhatian mereka (Kristen) terhadap pendidikan sangat bagus, dalam pembelajaran mereka sangat di siplin dan tertata rapih semua kegiatanya. Sikap toleransi yang ada di sini sebenarnya tidak hanya dalam pergaulan di sekolah, tetapi dalam pergaulan sehari-haripun mereka tetap selalu berbaur dengan baik.

${ }^{26}$ Supatman (59 tahun), Kepala Sekolah SDN Pantilaksana. Wawancara, Senin tanggal 10 Febuari 2019 di SDN Pantilaksanan.

${ }^{27}$ Supatman (59 tahun),......Wawancara, hari Senin tanggal Senin tanggal 10 Febuari 2019 di SDN Pantilaksanan. 
Beliau juga menegaskan, sebenarnya kehidupan beragama, sosial kemasyarakatan dan yang lainya sejak dahulu tidak pernah ada masalah khusus antara masyarakat Islam dan Kristen yang ada di kampung Kalaksanan. Memang pernah disini ada dua kejadian yang pertama tahun 90 an, dan kejadian yang kedua sekitar tahun 2001 jadi yang datang menyerang itu orang-orang luar di luar wilayah kampung Kalaksanan, ada yang dari Cipatujah dan daerah-daerah lain di sekitaran desa Cikawungading.

Tentunya sebagai pengajar Supatman dan guru-guru lainya tidak hanya memberikan contoh untuk bersikap toleransi, tetapi di waktu-waktu tertentu mereka juga selalu berusaha kepada anak didik untuk menjelaskan dan memehamkan untuk bersikap toleransi, misalnya dalam upacara hari senin selalu di singgung hal seperti ini dan dalam pembelajaran tentunya. ${ }^{28}$

Dari sikap diatas menunjukan bahwa dalam dunia pendidikan mulai sejak dini masyarakat kampung Kalaksanan sudah ditanamkan sikap toleransi yang baik sesama warga Kalaksanan, baik itu dalam lingkungan pembelajaran seperti sekolah formal, sekolah nonformal, pendidikan agama dan kehidupan sehari hari terutama bagi masyarakat Islam dan Kristen.

\section{Sosial Keagamaan}

Masyarakat Desa Cikawungading memandang bahwa perbedaan faham keagamaan adalah urusan individu dengan Tuhan-Nya. Keyakinan yang mereka pegang dan masalah keimanan tidak bisa dipaksakan. Kebebasan dalam hal memeluk agama sangat dijunjung tinggi serta perbedaan agama tidak menjadi jurang pemisah bagi mereka dalam berinteraksi antara pemeluk agama yang berbeda. Satu hal yang mereka junjung tinggi baik Islam maupun Kristen yaitu ketika mereka dewasa berhak memilih agama apa yang mau mereka anut asalkan mereka konsisten dalam satu pilihan dan menjadi manusia yang taat (iman) akan hukum agamanya masing-masing. ${ }^{29}$ Seperti halnya Supardi dia adalah anak ketiga dari lima bersaudara. Ayah dan ibunya adalah seorang Kristen

${ }^{28}$ Supatman (59 tahun),......Wawancara, hari Senin tanggal 19 Maret 2017 di SDN Pantilaksanan.

${ }^{29}$ Supardi (63 tahun). Pengurus Majlis Jemaat Gereja Kristen Pasundan Kalaksanan periode 2014 - 2018, sekaligus generasi ke empat sebagai sesepuh gereja. Wawancara, kedua, hari 5 Jaunari 2019 di Kalaksanan. 
Prostestan, kakak pertamanya seorang Katolik, kakak keduanya seorang Budha, beliau Kristen dan kedua Adiknya beragama Islam. ${ }^{30}$

Dari contoh di atas jelas bahwa perbedaan agama dalam ruang lingkup keluargapun tidak menjadi masalah. Dalam hal ini tentunya mereka menyadari betul perbedaan itu harus dibina dan tidak saling menggangu dalam beribadah. Secara formal sikap toleransi keagamaan ini terlihat dengan adanya suatu bentuk dialog antar pemuka agama di tingkat desa seperti MUI dengan Majlis Gereja yang mana mereka mengakomodir segala bentuk permasalahan yang berkembang di masyarakat, terlebih mereka membina pemeluk agamanya masing-masing.

Dari penemuan penulis di lapangan, adanya hubungan dan kerja sama sosial keagamaan di dalam masyarakat Desa Cikawungading dapat dilihat juga dalam kehidupan sehari-harinya dalam pembentukan nilai-nilai sosial yang harmonis. Hal ini bisa terlihat ketika salah satu agama sedang merayakan hari-hari besar keagamaan atau salah seorang sedang menyelenggarakan syukuran yang bersifat ritual keagamaan. Dalam hal ini mereka turut memeriahkan dan berpartisipasi dalam acara yang sedang dilangsungkan salah satu pemeluk agama manapun tanpa membedabedakan agama yang mereka yakini. Contoh sederhana ketika umat Islam sedang merayakan hari Idul fitri, tradisi umat Islam selalu selalu menyajikan beraneka ragam makanan dan mereka membagi-baginya kepada siapapun kerabat mereka khususnya tetangga tanpa membedakan agama apa yang mereka yakini. Begitupun sebaliknya, ketika umat Kristen sedang merayakan hari-hari besar keagamaannya, sikap orang Islam menghormati apa yang sedang dirayakan oleh masyarakat penganut agama lain, bahkan mereka (orang Islam) membantu menjaga ketertiban.

Pola hubungan dalam sikap toleransi sosial keagamaan yang terjadi di Kampung Kalaksanan Desa Cikawungading juga dapat kita lihat dari beberapa fenomena yang berkembang di masyarakat seperti halnya upacara kematian dan upacara-upacara kegamaan yang bersifat privat. Dalam hal upacara kematian contohnya ketika ada tetangganya meninggal baik Islam mupun Kristen mereka semuanya bersama-sama saling membantu proses pemakaman tanpa melihat apakah yang meninggal itu orang Islam atau Kristen. Yang membedakanya di sini adalah ketika ada

${ }^{30}$ Supardi (63 tahun).......Wawancara, kedua, hari Minggu 5 Jaunari 2019 di Kalaksanan. 
orang Kristen yang meninggal orang Islam hanya membantu dalam halhal tertentu seperti menggali kubur, mengantarkan mayat ke pekuburan dan memberi tahu kepada kerabat-kerabatnya yang lain, begitupun sebaliknya. Untuk masalah-masalah tertentu seperti mengurus mayat dari mulai memandikan sampai menguburkan mayat dilakukan oleh agamanya masing-masing karena hal ini dilakukan secara berbeda baik oleh Islam ataupun Kristen. ${ }^{31}$

Keadaan tersebut menunjukan bahwa sikap toleransi dan kebersamaan masyarakat dalam hal perbedaan agama tidak menjadi faktor penghambat, justru malah menjadi faktor perekat sosial yang kuat antara umat beragama Islam dan Kristen khusunya demi terciptanya kerukunan.

\section{Perkawinan}

pernikahan antara orang Islam dan Kristen sudah menjadi biasa hal seperti ini tidak bisa dihindarkan lagi karena mereka sudah hidup bersama dalam satu lingkungan yang sama sejak lama. Tidak ada hambatan atau pertentangan dari kedua belah pihak ketika ada warganya yang menikah beda agama. Bagi warga masyarakat Muslim dan Kristen yang ada di Kampung Kalaksanan sebelum mereka menikah terlebih dahulu diadakan kesepakatan dari kedua belah pihak keluarga (Islam dan Kristen) untuk memilih satu agama, apakah mereka bersedia menikah secara Islam dan masuk Islam atau mereka mau menikah secara Kristen dan masuk kristen. $^{32}$

Adapun tradisi pernikahan yang dilakukan oleh warga Muslim dan Kristen Kalaksanan sama halnya dengan tradisi pernikahan yang mayoritas dilakukan oleh semua warga yang ada di Desa Cikawungading pada umumnya. Tidak ada perbedaan diantara mereka, semua antusias dari mulai hiburan, rame-ramean dan tradisi upacara lainnya. Yang membedakannya disini adalah jika seorang Muslim menikahi seorang Kristen, lalu mereka sepakat untuk memeluk agama Islam maka di nikahkan sesuai tuntunan agama Islam begitupun ketika seorang Kristen

31 Supardi (63 tahun)......Wawancara, kedua, hari Minggu 5 Jaunari 2019 di Kalaksanan.

32 Supardi (63 tahun).......Wawancara, kedua, hari Minggu 5 Jaunari 2019 di Kalaksanan. 
Respon Masyarakat Muslim Terhadap Keberadaan Umat Kristen di Cikawungading Cipatujah Tasikmalaya Tahun 1996-2019| Abdul Baits

menikah dengan seorang Muslim dan mereka sepakat untuk memeluk agama Kristen maka di nikahkan sesuai tuntunan ajaran agama Kristen. ${ }^{33}$

\section{Respon Masyarakat Muslim Terhadap Keberadaan Umat Kristen di Cikawungading Cipatujah Tasikmalaya Tahun 1996-2019}

Agama Kristen di Kalaksanan jemaatnya berkembang secara turun temurun, hal ini yang menjadikan agama Kristen tetap bertahan sampai sekarang. Selain dari itu, adanya sikap terbuka dari masyarakat yang beragama Islam, dukungan dari pusat di dalam ruang lingkup yang berupa bantuan moral dan materi.

Pada tahun 1936 agama Kristen Protestan memasuki daerah ini sebagai agama baru yang sama seperti agama Islam memiliki ajaran dan tata nilai pada kehidupan manusia. Agama Kristen Protestan ini diperkenalkan oleh bangsa Belanda yang membuka areal perkebunan di Kalaksanan Desa Cikawungading. ${ }^{34}$

Kehadiran agama Kristen Protestan di Kalaksanan menjadikan para pemeluk agama Islam khawatir akan eksistensi agamanya, akan tetapi mereka tidak bisa apa-apa. Artinya para pemeluk agama Islam tidak bisa mengadakan perlawanan atau menolak keras terhadap keberadaaan agama Kristen Protestan tersebut. Hal ini disebabkan oleh situasi dan kondisi politik, ekonomi, dan taraf pendidikan mereka yang tidak mendukung pada saat itu.

Pemeluk agama Kristen Protestan yang tergolong minoritas itu berusaha menjaga dan menciptakan sikap toleransi beragama dengan pemeluk agama Islam yang ada di sekitarnya. Namun di sisi lain ada sebagian pemeluk agama Kristen yang memperlihatkan sikap-sikap tidak terpuji kepada pemeluk agama Islam. Hal ini yang kemudian merusak kerukunan beragama di antara keduanya, bahkan mengakibatkan terjadinya konflik antara kedua agama tersebut.

Selain faktor-faktor diatas disini juga akan dijelaskan bagaimana proses terjadinya konflik antara masyarakat Islam dan Kristen Protestan di Kampung Kalaksanan Desa Cikawungading Kecamatan Cipatujah Kabupaten Tasikmalaya. Seperti yang sudah dijelaskan diatas, konflik ini diawali dari

${ }^{33}$ Pdt. Arni Selvi Mince. B (30 Tahun)......Wawancara, kedua, Hari Minggu 19 Januari 2019 di Kalaksanan.

${ }^{34}$ Supardi (63 tahun). Pengurus Majlis Jemaat Gereja Kristen Pasundan Kalaksanan periode 2014 - 2018, sekaligus generasi ke empat sebagai sesepuh gereja. Wawancara, pertama, hari Minggu 5 Jaunari 2019 di Kalaksanan. 
beredarnya surat tentang larangan penebangan kayu secara ilegal pada hari Rabu tanggal 12 September 2001 yang mana surat tersebut diedarkan oleh Kepala Desa Cikawungading. Kemudian setelah beredarnya surat itu, di sisi lain Kepala Desa bersama DKM Kalaksanan bernama Indi dan orang-orang yang bersekongkol dengannya melakukan pengambilan kayu ke hutan untuk memenuhi pesanan kayu dari Pondok Pesantren Sukamanah. ${ }^{35}$

Apa yang dilakukan oleh Kepala Desa tersebut diketahui oleh warga setempat yang beragama Kristen kemudian menggugatnya karena warga mengganggap ketidak konsekuenannya Kepala Desa dalam menetapkan peraturan yang dibuatnya sendiri. Kepala Desa tidak menerima gugatan itu dan karena ketidaksukaan atas perilaku wargan Kristen ini, kepala Desa mengaitkan masalah ini dengan masalah yang pernah terjadi di tahun 1999 isu tentang pengkalungan huruf Arab kepada seekor anjing oleh salah seorang warga Kristen.

Isu pengkalungan huruf Arab dan pemakaian peci (kopiah) pada seekor anjing ini semakin meluas di sekitar Desa Cikawungading bahkan menyebar kepada aktivis-aktivis Muslim yang tergabung dalam forum santri di Kabupaten Tasikmalaya. Hal ini tentunya mengundang reaksi yang sangat serius terutama para tokoh-tokoh Islam setempat yang sebelumnya merasa tidak senang atas tindakan dan sikap salah seorang umat Kristen yang tidak menghargai umat Islam. ${ }^{36}$

Kemarahan umat Islam di Desa Cikawungading dan forum santri semakin memuncak. Dengan itu mereka mengadakan rencana untuk melakukan penyerangan terhadap warga pemeluk agama Kristen yang berada di Kampung Kalaksanan. Maka pada hari Rabu malam Kamis tanggal 12 September 2001 tokoh masyarakat beserta para Ulama Muslim setempat menyusun strategi penyerangan. Dimana secara sembunyi-sembunyi umat Islam yang dipelopori oleh H. Indi, K.H. Marjud dan Aj. Sopyan melakukan pemasangan stiker bertuliskan "Salam" pada setiap rumah pemeluk Islam, terutama yang berdekatan dengan rumah orang Kristen, dengan tujuan untuk membedakan antara warga Islam dengan warga Kristen. Disamping itu diinformasikan bahwa forum santri dari Kota Kabupaten Tasikmalaya

\footnotetext{
${ }^{35}$ Ujang Setiawan, Konflik antara Islam dengan Kristen Protestan ....... 74

${ }^{36}$ Ujang Setiawan, Konflik antara Islam dengan Kristen Protestan ........ 76
} 
Respon Masyarakat Muslim Terhadap Keberadaan Umat Kristen di Cikawungading Cipatujah Tasikmalaya Tahun 1996-2019| Abdul Baits

sebanyak 150 motor akan tiba pada malam Jum'at tanggal 14 September $2001 .{ }^{37}$

Di sisi lain tokoh masyarakat sekitar yang beragama Islam bernama Dedi Supriadi diantaranya tidak setuju atas tindakan yang akan dilakukan masyarakat Islam itu. Ia meminta kepada $\mathrm{H}$. Indi untuk menyelesaikan masalah tersebut dengan cara damai. Akhirnya H. Indi pun berhasil meredakan masa yang beragama Islam yang berada di sekitar Kampung Kalaksanan.

Untuk mengentisipasi kedatangan forum santri dari Kota Kabupaten Tasikmalaya pada hari Kamis tanggal 13 Sepetmber 2001, Dedi Supriadi memerintahkan ketua LPM Desa Cikawungading untuk melaporkan bahwa: "pada hari Jum'at di Kalaksanan akan kedatangan tamu yaitu forum santri dari kabupaten untuk menyerang penduduk yang beragama Kristen". Mendengar berita tersebut Kapolsek Kecamatan Cipatujah segera mengambil tindakan dengan cara menangkap oknum dari umat Kristen yang mengalungkan huruf Arab kepada seekor anjing dan akhirnya orang itu yang bernama Karep, pada tanggal 13 Sepetember 2001 segera dibawa ke Kapolres Tasikmalaya untuk diproses secara hukum. Penangkapan itu pun segera diumumkan kepada seluruh warga Desa Cikawungading tujuannya untuk meredam kemarahan warga Muslim. ${ }^{38}$

Sampai pada hari Minggu tanggal 16 Sepetember 2001, aksi penyerangan tersebut tidak terbukti. Kemudian Ketua LPM menyatakan kepada aparat bahwa daerah kampung Kalaksanan telah aman. Akhirnya penjagaan di daerah Kalaksanan dibubarkan pada hari Senin tanggal 17 Sepetember 2001 oleh Camat kecamatan Cipatujah. ${ }^{39}$

Tetapi setelah dibubarkanya pengamanan dan forum santri dari kota Kabupaten Tasikmalaya tidak datang, warga sekitar desa Cikawungading yang sebelumnya telah dipersiapkan secara serempak melakukan penyerangan terhadap penduduk Kristen yang berada di Kampung Kalaksanan. Penyerangan ini di bawah komando tokoh-tokoh Islam setempat yaitu dari daerah Pamayang yang dipimpin oleh K.H Marjud, dari daerah Cidadap di bawah pimpinan Aj. Sopyan. Mereka menyerang pemukiman dan tempat ibadah masyarakat Kristen (gereja). Penyerangan itu dilakukan Senin sore

\footnotetext{
${ }^{37}$ Ujang Setiawan, Konflik antara Islam dengan Kristen Protestan ........ 77

${ }^{38}$ Ujang Setiawan, Konflik antara Islam dengan Kristen Protestan ...... 77

${ }^{39}$ Ujang Setiawan, Konflik antara Islam dengan Kristen Protestan ...... 78
} 
Respon Masyarakat Muslim Terhadap Keberadaan Umat Kristen di Cikawungading Cipatujah Tasikmalaya Tahun 1996-2019| Abdul Baits

tanggal 17 September 2001 tepatnya puul 17.00 setelah selang beberapa jam dari pembubaran pengamanan aparat di Kampung Kalaksanan. ${ }^{40}$

Dalam penyerangan ini tidak ada korban jiwa karena sebelum terjadinya penyerangan, masyarakat Kristen Protestan sudah mengetahui bakal adanya penyerangan ini sehingga mereka (warga Kristen) pergi untuk mengungsi ke berbagai tempat diantaranya: Kantor Desa Cikawungading, ke hutan dan ke saudara-saudara mereka yang berada di daerah lain.

Dalam aksinya ini warga yang beragama Islam melakukan pembakaran dan perusakan tempat ibadah (gereja), rumah-rumah warga Kristen dan semua fasilitas yang dimiliki oleh warga Kristen. Dalam waktu sekejap yaitu kirakira pukul 22.00 WIB, pemukiman warga Kristen yang berada di Kampung Kalaksanan hangus dibakar dan yang tersisa hanya puing-puing dan bara api sisa dari amukan masa yang beragama Islam. Tidak hanya rumah warga yang berada di Kampung Kalaksanan, tetapi mereka (umat Islam) membakar rumah umat Kristen yang berada di daerah Pamayang dan kemudian mereka membubarkan diri. ${ }^{41}$

Sekitar pukul 24.00 WIB aparat keamanan dari Kapolsek Cipatujah kembali datang ke lokasi kejadian untuk melihat situasi yang telah terjadi dan mengamankan kembali Kampung Kalaksanan dari amukan warga muslim, mengevakuasi para warga Kristen dan membawanya ke kantor Kecamatan Cipatujah untuk diungsikan. Sejak saat itu pengawasan keamanan di Kampung Kalaksanan diperketat pemerintah, hal ini untuk mengantisipasi terjadinya penyerangan susulan. Di samping itu aparat pemerintah menangkap sebagian para warga Muslim yang dianggap sebagai provokator dalam kejadian itu. Para tokoh Islam yang menggerakan masa dan orang-orang yang terkait di dalamnya ditangkap untuk diperoses secara hukum. Tidak hanya diproses secara hukum masalah ini pun diselesaikan oleh pemerintah setempat melalui musyawarah dan kesepakatan bersama di antara kedua belah pihak yakni Islam dan Kristen terutama untuk membahas berbagai permasalahan yang telah mengakibatkan pertentangan di antara keduanya itu. Cara ini dikenal dengan istilah Konsiliasi dan editasi. ${ }^{42}$

Cara konsoliasi ini sebenarnya telah dilakukan sebelumnya pada tahun 1999 dalam menyelesaikan masalah pengkalungan huruf Arab pada seekor

\footnotetext{
${ }^{40}$ Ujang Setiawan, Konflik antara Islam dengan Kristen Protestan ...... 79

${ }^{41}$ Ujang Setiawan, Konflik antara Islam dengan Kristen Protestan ...... 80

${ }^{42}$ Dadang Suhermawan (46 tahun). Kepala Desa Cikawungading, Wawancara, Sabtu 8 Febuari 2019 di Kantor Desa Cikawungading.
} 
Respon Masyarakat Muslim Terhadap Keberadaan Umat Kristen di Cikawungading Cipatujah Tasikmalaya Tahun 1996-2019| Abdul Baits

anjing yang dilakukan oleh salah seorang pemeluk agama Kristen yang bernama Karep. Dimana para tokoh kedua agama yang disaksikan oleh aparatur pemerintahan setempat melakukan musyawarah dan kesepakatan bersama demi terciptanya kerukunan antar umat beragama di Kampung Kalaksanan Desa Cikawungading. Hasil dari musyawarah tersebut akhirnya dapat diterima oleh kedua belah pihak, terutama pihak Islam yang memaklumi tindakan tersebut dan memaafkanya. ${ }^{43}$

\section{Kesimpulan}

Agama Islam cukup lama berkembang di daerah Jawa Barat bagian Selatan (Cipatujah) yaitu sejak abad $17 \mathrm{M}$. Dalam perkembanganya itu, agama Islam tidak dapat dipisahkan dari tradisi lokal yang diwariskan oleh nenek moyangnya, baik tradisi asli leluhur maupun yang berasal dari pengaruh kebudayaan Hindu Budha. Maka tidak mengherankan apabila di daerah ini, banyak ditemukan ritual keagamaan yang di dalamnya terdapat unsur Islam, Hindu dan Budha (sinkretisme).

Pada tahun 1936 M agama Kristen Protestan memasuki daerah ini sebagai agama baru yang sama seperti agama Islam memiliki ajaran dan tata nilai pada kehidupan manusia. Kehadiran agama Kristen Protestan di Kalaksanan menjadikan para pemeluk agama Islam khawatir akan eksistensi agamanya, akan tetapi mereka tidak bisa apa-apa. Artinya para pemeluk agama Islam tidak bisa mengadakan perlawanan atau menolak keras terhadap keberadaaan agama Kristen Protestan pada awal keberadaanya. Hal ini disebabkan oleh situasi dan kondisi politik, pada saat itu.

Pada awal keberadaanya, sekitar tahun 1936 sebelum Islam menyebar ke wilayah pedalaman (kampung Kalaksanan sekarang) warga masyarakat kampung Kalaksanan hampir seluruhnya beragama Kristen. orang-orang Jawa dari Salatiga yang menempati wilayah ini di bawah kepengurusan GKJ (Gereja Kristen Jawa) pada masa penajajahan Belanda oleh Tuan A. Van Emmrik. Tujuan utama mereka ke wilayah Cikawungading ini untuk membuka lahan pertanian. Namun dikarenakan orang-orang Jawa yang dibawa beragama Kristen akhirnya mendirikanlah sebuah tempat peribadatan (Gereja)

Suatu hal yang perlu diketahui disini adalah perbedaan yang ada pada masyarakat Kampung Kalaksanan Desa Cikawungading tersebut tidak

${ }^{43}$ Ujang Setiawan, Konflik antara Islam dengan Kristen Protestan ...... 80 
menjadikan mereka hidup dalam ketegangan hingga menimbulkan suatu konflik seperti konflik-konflik yang sering terjadi di berbagai daerah di Indonesia, sekalipun terjadi konflik hal itu terjadi karena konflik sosial dan bukan menyangkut agama terlebih adanya pihak ketiga yang sengaja ingin memecah belah kerukunan yang ada. Namun kehidupan mereka justru sangat harmonis, bisa hidup secara berdampingan dan sangat menjunjung tinggi toleransi dalam beragama. Dimana setiap masyarakat bukan hanya mengakui keberadaan hak agama lain tetapi juga terlibat dalam usaha memahami perbedaan dan persamaan dari setiap masing-masing penganut agama yang ada. Faktanya bahwa setiap masyarakat yang berbeda agama tersebut dapat berinteraksi secara positif dalam lingkungan kemajemukan tersebut.

Hal seperti ini tentunya tidak terjadi secara alamiah atau datang dengan sendirinya. Jelas ada usaha-usaha yang mereka lakukan untuk mempertahankan kerukunan seperti itu. Dimana usaha-usaha tersebut mereka implementasikan dengan baik dalam kehidupan sehari-hari. Pola kerukunan umat beragama yang terjadi di Kampung Kalaksanan Desa Cikawungading sangatlah dinamik, hal ini dapat terlihat dari beberapa pola kerukunan yang berkembang di masyarakat, misalkan pola hubungan sosial keagamaan dan pola hubungan sosial kemasyarakatan. Selain itu, terdapat pula faktor-faktor yang mempengaruhi sikap toleransi yaitu: ikatan kekeluargaan, perkawinan, kerjasama pereknomian, gotong royong, salig menghormati dan menghargai antara umat beragama. 
Respon Masyarakat Muslim Terhadap Keberadaan Umat Kristen di Cikawungading Cipatujah Tasikmalaya Tahun 1996-2019| Abdul Baits

\section{Daftar Sumber}

\section{Tertulis}

Aldi, Riwayat Desa Cikawungading, ditulis pada tahun 1998

A.A Khaerussalam, Sejarah Perjuangan Syekh H. Abdul Muhyi Waliyullah

Pamijahan, (Tasikmalaya: Grafiana Offset. Cet IX 1997). hlm. 9-10

Data Monografi dan Demografi Desa Cikawungading Tahun 2018

Endang Saefudin Anshari, Kuliah Al-Islam (Jakarta: P.T. Raja Grafindo Persada. 1992)

Helius Sjamsudin, Metodologi Sejarah, (Jakarta: Departemen P\&K, Direktorat Pendidikan Tinggi. 1996)

Keputusan Pemerintah NO. 15 Tanggal 18 Agustus Tahun 1936 dan Lembaran Negara No. 176 Tanggal 17 April 1936 Tentang Pendirian Gereja dan Pengembangan Agama Kristen Protestan.

Kuntowijoyo, PengantarIlmuSejarah, (Yogyakarta: Bentang, 1997).

Louis Gottschalk, Mengerti Sejarah, (Jakarta: Universitas Indonesia, 1975).

Sartono Kartodirdjo, Pendekatan Ilmu-ilmu Sosial dalam Metodologi Sejarah, (Jakarta: Gramedia, 1992)

Ujang Setiawan, Konflik antara Islam dengan Kristen Protestan di Kelaksanan

Desa Cikawungading Kecamapat Cipatujah kabupaten Tasikmalaya Tahun 2001. (Bandung: Skripsi UIN Sunan Gunung Djati Bandung, 2005). hlm. 50.

\section{Lisan:}

Dadang Suhermawan (46 tahun). Kepala Desa Cikawungading, Wawancara, hari Sabtu 8 Febuari 2019. di Kantor Desa Cikawungading.

Pdt. Arni Selvi Mince. B (30 tahun). Kepala Pendeta Gereja Kristen Pasundan Kampung Kalaksanan. Wawancara, hari Minggu tanggal 19 Maret 2019 di Kalaksanan.

Supardi (63 tahun). Pengurus Majlis Jemaat Gereja Kristen Pasundan Kalaksanan periode 2014 - 2018, sekaligus generasi ke empat sebagai sesepuh gereja. Wawancara, pertama, hari Minggu 5 Januari 2019 di Kalaksanan.

Supatman (59 tahun), Kepala Sekolah SDN Pantilaksana. Wawancara, Senin tanggal 10 Febuari 2019 di SDN Pantilaksanan

Sukati (61 tahun). Masyarakat Muslim. Wawancara, hari Sabtu 18 Januari 2019 di Kampung Kalaksanan. 
Respon Masyarakat Muslim Terhadap Keberadaan Umat Kristen di Cikawungading Cipatujah Tasikmalaya Tahun 1996-2019 | Abdul Baits 